\title{
The Impeding Drivers of Risks at Private Higher Education Institutions in Jordan: An Analytical Approach
}

\author{
Hala Abdulqader Sabri \\ Petra University, Amman-Jordan \\ habdulqader@uop.edu.jo
}

\begin{abstract}
This study provides an in depth assessment of the main drivers of risk impeding private higher education institutions in Jordan. The study adopts an analytical approach that incorporates reviewing available literature and conducting interviews and discussions with some shareholders and board of trustees' members in addition to faculty members and students of private universities. The analysis revealed that although private universities in Jordan are making progress and provide important contributions to the economy, however, they face important strategic and operational risks in addition to other compliance, financial and reputational risks. These risks include educational delivery systems, quality of academic programs, executive management, competition, and utilization of new technologies, compliance with accrediting agencies, financial issues, societal perception, students' violence, and demographic challenges. The study concludes that private universities need to place risk management plans to effectively deal with the all risk indicators analyzed in the study. Recommendations on how to implement a risk management plan are also presented and highlighted.
\end{abstract}

Keywords: Risk, Private, Higher Education Institutions, Jordan.

\section{Introduction}

The trend towards privatization of higher education is increasing in many Arab countries and private higher education sector is gradually complementing the public higher education sector in countries such as Jordan, Egypt, Qatar and the United Arab Emirates. However, although many Arab countries opened their academic systems to foreign and private competition in order to improve these systems, the results have been complicated. Over the last five years, the GCC countries, for instance, have expended at least $\$ 50$ billion on higher education reflecting the rapid growth in this sector over the last decade. Despite that, many believe that higher education institutions in the Arab countries continue to wrestle with risks brought about by inadequate responses to pre-existing and unresolved challenges.

A case in point is Jordan where private, for profit, higher education institutions have emerged in the early 1990s because of the rapid growth of higher education, which called for private investment in this sector. Private universities in Jordan are heavyweight academic actors that provide an important contribution in supporting the Jordanian economy and serve the large number of students who are willing to pursue their academic education. However, although there has been rapid quantitative expansion of private higher education institutions, many believe that this expansion has not yet been accompanied by a sufficient qualitative shift. This with other challenging strategic and operational factors, constitute significant risks for private higher education in Jordan. Therefore, in order to understand the scope of these challenges and risks, this study aims to assess the impending risks that private universities face, or most likely to, in the future. Understanding the factors that are most likely associated with risk in private higher education in Jordan is also required and timely, to keep them up with the rapidly growing internal, regional and international competition that put them in front of tough challenges and risks. Hence, to achieve its aim the study poses the following questions: what are the potential risk factors that private universities in Jordan face? In addition, what strategies could be taken to manage them?

\section{Research Methodology}

Myers (2000) argues that one of the greatest strengths of the qualitative approach is the depth of explorations and descriptions. Therefore, to gain a better understanding of the most important risks impeding private higher education institutions in Jordan, the researcher believes adopting a qualitative content analysis, that includes reviewing available literature, is the most appropriate to use. Moreover, Temple (1997) argues that the researcher's interest and experience are critical to the success of the research. Hence, the choice of the private academic institutions in Jordan as a research area was shaped 
by a combination of personal interest, experience and opportunity. Being a private university faculty member herself, the researcher had the chance to conduct interviews with some private universities' representatives and carry out discussions with other faculty members and students who provided insights concerning present teaching methods and practices and their views regarding opportunities for employment. Finally, in analyzing the risks that are currently occurring, or have the potential of occurring, in private academic institutions in Jordan, the author adopted Cassidy et al., (2001) classification of the strategic, operational, compliance, financial and reputational risks facing academic institutions as reviewed in the literature. It should be noted, however, that these risks are associated and overlap with each other. Risk and Risk Management: Webster's Dictionary defines risk as "the possibility of suffering loss, injury, disadvantage, or destruction" (Webster's Dictionary 1981: 1961]. Whitfield (2004) argues that risk and risk management are at the forefront of the organization's strategic planning agenda but before risk management solutions can be developed, the current drivers of risk must be identified first then evaluated.

Risk management is applied in a number of diverse disciplines. It often focuses on matters of insurance when assessing areas of risk in business. In the best-run organizations, risk management is synonymous with good management and good governance. People in the fields of statistics, economics, psychology, social sciences, biology, engineering, systems analysis, operations research, and decision theory, among other disciplines, have been addressing the field of risk management. Kloman (1992: 299) asserts, "risk management is an art that properly should be concerned with the anticipation of future events rather than reaction to past events". Social analysts, politicians, and academics believe, on the other hand, argue that it is the management of environmental and nuclear risks that appear to threaten people's existence. To bankers and financial officers it means technical use of currency distortion and interest rate exchange. Insurance specialists consider it a mode of coordination of challenging risks and the reduction of insurance costs. Meanwhile hospital administrators look at it as a quality assurance, safety professionals look at it as reducing accidents and injuries (Kloman, 1992).

Risk Management in Higher Education: The Higher Education Funding Council for England (HEFCE, 2005) indicates that risks can exist at a number of different levels in higher education institutions: corporate or strategic, faculty, departmental and personal level. The HEFCE (2005) cautions, however, that risk management should not be seen as a process for avoiding risk. In the best-run organizations, risk management is synonymous with good management and good governance. As such when used well it can actively allow an institution to take on activities that have a higher level of risk because the risks have been identified, well managed, and the continuing risk is thereby lower. Helsloot and Jong (2006, September) believe that a risk that results of external causes is less amenable to control than a risk that arises from internal causes. They add also that risks may have an internal impact or external impact. In the case of an internal impact, the institution is the primary owner of the problem and thus has primary responsibility for tackling it. In the case of an external impact, tackling the problem entails consultation with external bodies. Ethics Point (2004) identified financial, research, human resources, athletic \& safety as main risk factors facing universities. On the other hand, Whitfield (2004) asserts that most academic institutions now are challenged by fierce competition, increased external inquiry, and powerful new technologies. Cassidy et al., (2001) state that some academic institutions equate risk management with crisis management, compliance risk or with means of minimizing dangers resulting from violations of university policies or of governmental laws and regulations.

Cassidy et al., (2001) pertain that one of the first steps in any risk management assessment is to consider the drivers, or factors, of risk that introduce risk into an environment. They identified strategic, operational, compliance, financial and reputational risks as mostly susceptible issues to risk that directly affect the institution's revenues and asserted their need for effective dealing by academic institutions. Strategic risk affects an organization's ability to achieve its goals. It includes, among other things, educational delivery systems comprising: students, faculty, executive management, staff, and accrediting agencies; quality of academic programs comprising students, faculty and executive management and increasing customers' expectations. Operational risk affects an ongoing management process. It includes: new technologies, financial issues, research, intellectual property, human resource management, increased competition and the students. Compliance risk affects conformity with externally imposed laws and regulations as well as with internally obligatory policies and procedures concerning safety, conflict of interest, and the like. Financial risk results in a loss of assets. Reputational risk affects an organization's reputation, brand, or both, and may result from an organization's failure to effectively manage any or all of the other risk types; it involves external perception of the university. 
Overview of Higher Education in Jordan: Education has played a transformative role in the development of Jordan from an agrarian economy to an urban, promising nation. Jordan's population has a very high literacy rate of 91.1 percent and therefore, it is ranked 92 in the world according to literacy rate as included in the United Nations Development Program (UNDP, 2009), and the fourth in the Arab world after Kuwait (94.5), the Palestinian Authority (93.3) and Qatar (93.1). The Jordanian higher education system offers options of a differentiated system of higher education institutions (universities and community colleges) and patterns of ownership (public and private). Access to higher education in Jordan is open to holders of the General Secondary Education Certificate (Tawjihi) and the credit-hour system has been adopted at all universities in Jordan. During the last decades different strategies were presented on higher education in Jordan, the last of which is the "National Strategy for Higher Education 2007-2012.)

Historical Development of Higher Education: Higher education in Jordan started in 1951 with a oneyear post-secondary teacher-training institute. The first public university (the Jordan University), was established in 1962 with 167 students, and the first private university (Amman Private University), was established in 1990 with 1324 students. Demand for university education has grown rapidly between the years $2000 / 2001$ and $2006 / 2007$ from 77,841 to 218,900 students. Over the same period, enrollments in private universities grew from 36,642 to 55,744. The Ministry of Higher Education and Scientific Research (MoHESR, 2010) estimates the current enrolled students in both public and private universities at nearly 243,251. Out of this total (29406) comes from Arab or foreign nationalities; 15243 in public universities and 14163 in private universities. Figure 1 illustrates number of enrolled students in public and private universities (1990-2007.)

\section{Figure 1: Enrolled Students in Public \& Private Jordanian Universities (1990-2007)}

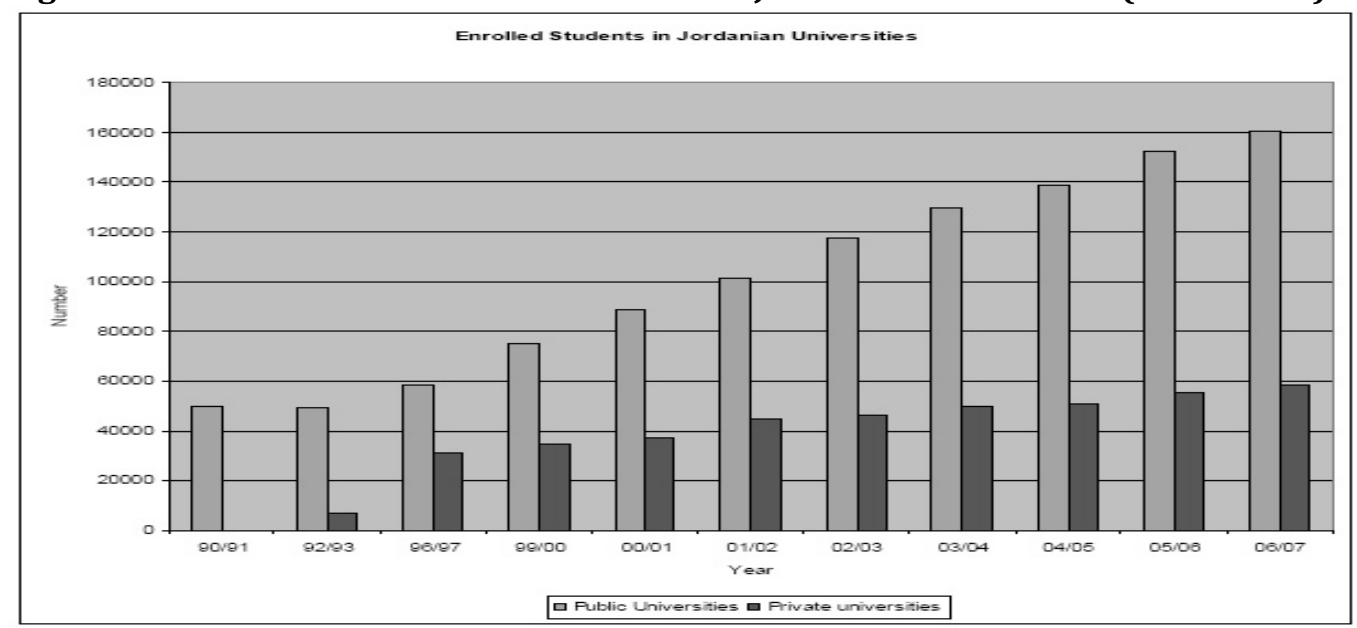

Source: Statistics of the Jordanian Ministry of Higher Education and Scientific Research (2010), www.mohe.org.jo

Accreditation of Higher Education Institutions: Higher education in Jordan is the responsibility of the MoHESR, which was established in 1985. It comprises the Council of Higher Education (HEC), the Higher Education Accreditation Commission (HEAC) and the Higher Committee for Scientific Research (mohe.org.jo). In 1996, a Council for Higher education was established as a national body for quality assurance and accreditation. The activity of the Council, however, had mainly been restricted to licensing and recognizing programs in private universities, as public universities are self-evaluated through their boards of trustees, but it did not extend to in-depth assessment leading to accreditation as usually practiced at the international level.

In 2007, the Higher Education Accreditation Commission (HEAC) was set up in the Council's place, administratively and financially independent with a mandate over private and public universities and all foreign institutions of higher education affiliated with Jordanian universities. HEAC objectives are to enhance and guarantee quality in higher education, to encourage universities to interact with international research institutions and accreditation commissions, and to upgrade higher education on the basis of internationally recognized criteria. Moreover, the HEAC is empowered to audit, evaluate, and accredit institutions of higher education, making sure that they comply with all pertinent regulations. The 
Commission is also charged with the establishment and management of The National Testing Centre for graduation and admission.

Private Universities in Perspective: The emergence of private, for profit, higher education institutions in the early 1990s came as a result of the rapid growth of higher education in Jordan which called for private investment in this sector. Establishing private higher education institutions, however, needs the approval of the Board of Higher Education. Currently, there are (18) private universities illustrated in Table 1. Eleven of the universities listed in Table 1 offer undergraduate and graduate programs. The remaining universities are dedicated mainly for undergraduate teaching.

Table 1: Private Universities and Regional Higher Education Institutions in Jordan (2009/2010)

\begin{tabular}{|c|c|c|c|}
\hline \multicolumn{2}{|c|}{$\begin{array}{c}\text { Name } \\
\text { Private Universities }\end{array}$} & \multirow{2}{*}{$\begin{array}{l}\text { Programs } \\
\text { Graduate/Undergraduate }\end{array}$} & \multirow{2}{*}{$\begin{array}{l}\text { Website } \\
\text { www.aau.edu.jo }\end{array}$} \\
\hline 1 & Amman Arab University & & \\
\hline 2 & Middle East University & Graduate/Undergraduate & www.meu.edu.jo \\
\hline 3 & Jadara University & Graduate/Undergraduate & www.jadara.edu.jo \\
\hline 4 & Amman Private University & Graduate/Undergraduate & www.amman.edu \\
\hline 5 & Applied Science University & Graduate/Undergraduate & www.asu.edu.jo \\
\hline 6 & Philadelphia University & Graduate/Undergraduate & www.philadelphia.edu.jo \\
\hline 7 & Al-Isra University & Graduate/undergraduate & www.isra.edu.jo \\
\hline 8 & University of Petra & Graduate/Undergraduate & www.uop.edu.jo \\
\hline 9 & Al-Zaytoonah Private University & Graduate/Undergraduate & www.alzaytoonah.edu.jo \\
\hline 10 & Jerash Private University & Graduate/Undergraduate & www.jerashun.edu.jo \\
\hline 11 & $\begin{array}{l}\text { Princess Sumaya University for } \\
\text { Technology }\end{array}$ & Graduate/Undergraduate & www.psut.edu.jo \\
\hline 12 & Zarqa Private University & Undergraduate & www.zpu.edu.jo \\
\hline 13 & Irbid National University & Undergraduate & www.inu.edu.jo \\
\hline 14 & Jordan Academy of Music & Undergraduate & www.jam.edu.jo \\
\hline 15 & $\begin{array}{l}\text { Jordan Applied University College } \\
\text { of Hospitality and Tourism } \\
\text { Education (JAU) }\end{array}$ & Undergraduate & www.jau.edu.jo \\
\hline 16 & $\begin{array}{l}\text { Faculty of Educational Sciences and } \\
\text { Arts-UNRWA }\end{array}$ & Undergraduate & www.fesa.edu.jo \\
\hline $\begin{array}{l}17 \\
\mathbf{R e}\end{array}$ & $\begin{array}{l}\text { Red Sea Institute of Cinematic Arts } \\
\text { gional Institutions and Universities }\end{array}$ & Undergraduate & www.rsica.edu.jo \\
\hline $\begin{array}{l}1 \\
8\end{array}$ & $\begin{array}{l}\text { The World Islamic Science \& } \\
\text { Education University }\end{array}$ & Graduate/Undergraduate & www.wise.edu.jo \\
\hline $\begin{array}{l}1 \\
9\end{array}$ & $\begin{array}{l}\text { The Arab Academy for Banking and } \\
\text { Financial Sciences (AABFS }\end{array}$ & Graduate/Undergraduate & www.aabfs.org \\
\hline $\begin{array}{l}2 \\
0\end{array}$ & Arab Open University & Undergraduate & www.aou.edu.jo \\
\hline
\end{tabular}

Source: Ministry of Higher Education and Scientific Research website (mohe.org.jo)

Private universities are heavyweight academic actors which provide an important contribution in supporting the Jordanian economy and serve the large number of students who are willing to pursue their academic education. These universities have seen a rapid increase in enrollment which grew by about 18 percent annually from 36,642 to 55,744 during the period from 2000 to 2006. The MoHESR (2010) estimates the number of enrolled students in private universities in 2009 at 59,958 thousand students among them 14,163 thousand from Arab and foreign countries.

Drivers of Risk in Private Higher Education Institutions, Strategic Risk: Quality of Academic Programs and Educational Delivery System: Universities have a long-term interest in protecting their brand. But quality control is one of the great unsolved problems in education (the Economist, 2005, February 26). Many believe that while there has been rapid quantitative expansion of the higher education system in Jordan, it has not yet been accompanied by a sufficient qualitative shift (Burke and Al-Waked, 1997; Sarayrah, 2003; Mahmoud, 2004; Kamal, 2007; W.B, 2009; Bataeineh, 2008; and Kanaan et al., 2009). 
A World Bank report (2009, April 21st) indicates that Jordan's higher education system has evolved over the past five years but not fast enough to meet the needs of a knowledge-based economy. With the exception of a few isolated cases, the vast majority of the higher education institutions lack the necessary quality of instruction, independent leadership and progressive curricula that would train students to complement the needs of potential employers. Kanaan et al., (2009) also believe that private universities have not delivered centers of academic excellence. Instead, the domination of profit making has dominated the scene resulting in little to no incentive to invest in research and development.

Burke and Al-Waked (1997) identified the basic problem of private universities in that they were established as a "quick fix" for the growing access deficit in a system without surplus money, and where the existing money was not effectively spent. They pertain that private universities were expected to deliver a unique and modern methods of teaching and learning, but unfortunately, they have followed the public universities traditional way in curriculum and delivery rather than reaching out for innovation and creativity. Kamal (2007) asserts also that higher education institutions in Jordan are still teaching rather than learning institutions and lack scientific research and the ability to have an impact on the society. Mahmoud (2004, March 15) believes also that the average spending per student in Jordan is still low, estimated at 2500 \$ annually, compared to 45000 \$ in some developed countries. Therefore, Mahmoud suggests that Jordan's ability to reach its goal of becoming more competitive within the global economy will be largely dependent upon the orientation of its higher education graduates.

Faculty: Theoretically, a university exists so that its members can teach, think and learn, making them into "staff ", however, risks losing the ethos which has given universities their character and value (the Economist, 2005, February 26). Faculty members in private universities are appointed through contracts and not on tenure basis. The duration of the contract may be one to three years in most cases, and is subject to renewal with the agreement of both parties. Therefore, many of these faculty members lack job security and feel pressured from losing their jobs or being terminated before the end of their contracts. Despite that, the dramatic increase of private universities in Jordan created a vast competition that resulted in shortage in qualified academic staff. El-Tarawneh (2010, March 13) warned, for instance, that by 2016 Jordanian universities will be in need for 6000 faculty of doctorate degree holders. In addition, faculty increases have not been able to keep up with the growth in students' enrollment, which intensified the problem of inefficiency. Kanaan et al., (2009) believe that despite the fact that the total number of academic staff has been increasing in recent years, the student- teacher ratio has not improved. In 2007, the student-teacher ratio was 25:1 in private universities compared to 32:1 in public universities. Ortmann et al., (1998) indicate also that the shortage in full time academic staff at private universities called for the adaptation of various forms of outsourcing, as close to 50 percent of courses are taught by temporary teaching staff.

In addition, foreign and Arab academic expertise, especially Iraqis, has been invested in Jordan, and local higher education institutions were and still in need of their qualifications. Al-Zubaidi and Al-Zubaid (without date) estimate that 700 Iraqi professors work in Jordanian universities, 50\% of them in private universities as illustrated in Figure 2 (mop.org.jo). Some fear, however, that the shortage in qualified faculty will proliferate once the Iraqi teachers go back to Iraq.

\section{Figure 2: Distribution of the Foreign Teaching Staff at Selected Private Universities}

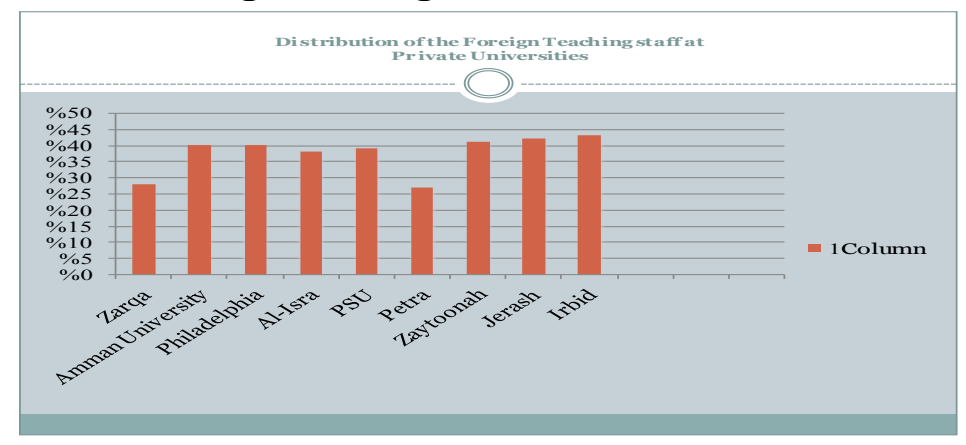

Source: Ministry of Planning, Cluster Studies, Higher Education cluster 2000, www.mop.org.jo

Moreover, Sarayrah (2003) notes that regional competition, especially from universities at the GCC courtiers, for holders of degrees from Western universities, left Jordanian universities infiltrated with 
teaching staff who graduated from universities of the Far East and East Europe who seem to lack required skills, English language competence, attitudes or incentives to meet the creative challenges of an energized system. Moreover, faculty members in many private universities still use outdated teaching methodologies; earn meager salaries and are not responsive to voluntary training in modern teaching methods. In addition, Sarayrah (2003) argues that as the requirements for promotion is mainly based on the number of published articles and evaluated research, most faculty dedicate their time to publishing than teaching and giving little weight to student and colleagues' evaluation and distinction in teaching or community service.

Students: Al-Maani (2008) and the Ministry of Planning cluster study (2000) found that most Jordanian graduates lack practical and up-to-date knowledge, analytical skills, efficient computer and language skills and hence they were not qualified to enter the labor market. Al-Maani believes that the roots of the problem is in secondary education graduates who lack analytical, computer and language skills which make them ill prepared for higher education. Sarayrah (2003) believes that students' lack of incentives towards education or to excel in their study is due to the shortage of jobs in the market, in addition to the exiting discrimination between those who are able to get a job through social connections (wasta), and those who are not. The 'wasta' phenomenon forms a widespread students' perception that they do not need sophisticated education or working hard but social connections to get a job, especially in the civil service.

Kanaan et al., (2009) attribute the high unemployment rate among university graduates, estimated at 15 percent, to poor quality of education and outdated educational system that is geared towards preparing students to serve in the public sector, resulting in severe mismatches between the education system and the labor market. Kanaan et al., (2009) argue that the public sector nowadays is shrinking while the private sector is expanding. With the move towards more market based economies in the region, the demand for particular skills is increasing, making much of the material taught in the existing higher education system obsolete.

Governance and Executive Management: In addition to higher education law private universities fall under the regulation of the companies' law as public or private shareholding companies. Jordanian universities' Law (20) for 2009 re-institutionalized private universities as educational institutions while guaranteeing the right of investors, denoting that they have their own organizational, administrative, technical and financial structure affiliated to the President directly. The law stipulates also that any private university should obtain two licenses to operate, one from the Ministry of Trade and Industry to oversee the financial components, and another from the Higher Education Council, to oversee the educational ones.

A Board of Trustees (BoT) and two main sub boards govern private universities: the University Council and the Dean's Council. The higher education law banned any investor from being appointed as university president, specifying that he/she should hold a minimum of a bachelor's degree to be appointed on the Board of Trustees (BoT). BoT of a private university has fourteen members in addition to the Chairman and is appointed by the Board of Higher Education (TEMPUS, 2010). The BoT usually nominates the president of the university for approval by the Board of Higher Education and is responsible for supervising the general activities of the University. In addition, BoT ensures the implementation of academic policies; boosts ties with local communities; appoints the Vice-President and Dean; recommends to the Board of Higher Education the establishment of faculties, departments, institutes, and centers, as well as academic programs and specializations; and finally it determines the tuition fees, and approves the annual budget and annual report after recommendation from the University Council. The University Council is chaired by the President and comprises representatives from the various categories of stakeholders, including representatives from the local communities. It is responsible, among other things, for the quality of the services offered by the university (teaching, research, training, and community service). The Deans' Council is chaired by the President and has the Vice-President(s) and Deans as members. Most academic decisions are made by the Council who is commissioned to run the day-to-day activities of various faculties, departments and sections, throughout the university.

The Economist magazine article (2005) indicates, however, that running universities in a way that suits a competitive environment does not mean necessarily adopting a corporate model, with a board of directors and a chief executive. Therefore, many believe that one of the major problems facing private universities in Jordan is the imprecise relation between investment and academia. Al-Maani (2002) 
believes, for instance that there is no clear and distinct line between academic and profit making issues in private universities. Al-Maani called, therefore, for setting clear rules that grants a university's president more autonomy and prevent investors from interfering with academic matters. Abu-Rumman (2008, September 25) argues also that private higher education institutions have transformed into business and thus have missed the opportunity to present themselves as centers of academic excellence. Arabeyat (2008, September 25) believes that although the law specified that owners of the private university should be a not-for-profit group, private investors were able to maneuver the law and established forprofit institutions instead. The resultant risk of this unbalanced situation, as argued by Al-Qaraleh (2007, May) is the negative consequences reflected on the students, faculty members and delivery system of private universities.

Operational Risk: Utilization of Information Technology: Al-Farawati (2001, December 21 $1^{\text {st }}$ argues that within Jordan's higher education system, there has been minimal penetration of IT and even less of communication and networking that is so much a factor in both global education and employment. The Arab Human Development Report (2003) also indicates that network services, such as e-mail and web access at Jordanian universities, are not part of the infrastructure that students and faculty routinely use. The report added also that looking into the use of computer based education, faculty members are not trained in integrating technology into teaching, and discipline related software has not been made available. Therefore, the UNDP suggests that to become effective, any IT strategy in Jordan should address the fact that the availability of computers is limited and even aggravated because few students have access to computers once they leave home.

Competition: In addition to competing for students and qualified staff among and between themselves, private universities also face competition from other Jordanian public universities who have special programs targeting students who are not admitted within the regular admission procedure through the Parallel Program. Admission into this program is more relaxed than the regular one, but tuition fees are considerably higher (TEMPUS, 2010). Moreover, the perceivable competition, international mobility of students and offering of higher education courses across national boundaries put private universities in Jordan in front of tough competition and risk.

The Arab world is experiencing a surge in higher education, along with its privatization and its internationalization. While in 1940 there were only ten universities in the MENA countries by 2007 their number had reached 260 (Mazawi, 2004). Last to participate in this academic boom have been the GCC countries. Eight universities were operating in Saudi Arabia in 2003, but at least 100 additional universities and colleges have been created there since (Krieger, 2007, a). The United Arab Emirates and Qatar have established 40 foreign branches of Western universities over the same period. Investment in private higher education in other neighboring countries, especially in the Gulf, is providing alternative opportunities for students in the region and putting private Jordanian universities in front of fierce competition. Added to this, is the competition resulting from the public institutions affiliated with American or European institutions of higher education who are also on the rise in Jordan and other neighboring countries. Among these Sunderland University, New York Institute of Technology, DePaul University, University of Hudersfield, University of Dublin and University of Ohio (mhe.org.jo). Moreover, The American Universities in Dubai, Abu Dhabi and Sharja, Ajman University of Science and Technology and Cornell University in Qatar, among others, are also accessible to students in the GCC countries (Krieger, 2007, b).

The Demographic Challenge: The growing youth population is an important and major risk that the Jordanian educational system is facing now which demands the continued expansion of the educational system. Kanaan et al., (2009) estimate that the demand for higher education is forecast to grow much more rapidly than in the past due to the rapid growth of school-aged population; improvements in secondary enrollment rates and the rising incomes in Jordan. This demographic risk is driven by the fact that higher education has a value of its own in the Jordanian society, irrespective of its functional value. Jordanians give provision of higher education to their children top priority and are willing to sacrifice their scarce resources for this purpose, or lobby the government and other groups to attain a scholarship for their children.

The World Bank (2008) estimates the level of households spending on higher education, relative to the overall household spending, around 4 percent. Badran (1985) contends, in this regard, that despite the unprecedented unemployment of university graduates, universities in Jordan continue to flood the 
market with thousands of graduates who are unable to get jobs. The World Bank (2009, April 21st) confirms that the increasing size of cohorts will continue to pressure the higher education system in Jordan until 2016, as the numbers of students entering university is projected to increase to 92,000 per year by 2013 up from 50,469 in 2005. Therefore, given the Government's budget constraints, higher education in Jordan will need to develop strategies to cope with this demand including relying more on the private sector. The regulatory framework for private universities, however, is highly restrictive, limiting their ability to respond to the influx of students (W.B, 2009, April 21 ${ }^{\text {st }}$ ).

Escalating Students' Violence and carrying of weapons in both public and private universities constitutes another major risk because it involves destruction of the university's property. Murad (2010, April $12^{\text {th }}$ ) finds it unacceptable for university students to use violent acts to resolve a tribal dispute, or otherwise, within the university's premises. The carrying of weapons, until the present, however, is not seen by most universities as a major risk, and accordingly virtually no steps are taken to detect weapons or to prevent people entering institution premises while carrying a weapon. At the time of writing this study many cases of incidents occurred at private universities involving knifes and firearms in the possession of students. However, no statistics are available for the carrying of weapons in private institutions. Although higher education institutions in Jordan have so far been spared any serious problems in this area, there is no guarantee that the problem will escalate in the future. Quite a few institutions indicated that they recognize this risk and are alert to it. Following escalating incidents of student violence, teams of experts and academics have met several times in order to carry out a risk analysis of the situation. Murad (2010, April 12 $2^{\text {th }}$ ) stresses the need to addressing this problem at its roots and urges taking action to put a plan in place to ensure that universities become foundations of intellectual, scientific and political exchange.

Compliance Risk: During the last two decades several laws/decrees have been issued to govern higher education in Jordan: Higher Education Act number (28) for 1985, Public Jordanian Universities Act number (29) for 1987, Private universities Act number (19) for 1989, Higher Education Provisional Law number (41) for 2001, the "Law of Higher Education (23) for 2009" and finally "The Jordanian Universities Law (20) for 2009" which gave universities more independence in managing their administrative as well as financial matters (MoHESR, 2010). El-Gharaybeh (2004, September 17) warns, however, that the vast number of laws and legislation that have been issued on higher education represents a major risk to universities and concerned bodies.

Establishing private higher education institutions needs the approval of the Board of Higher Education. Moreover, to be able to operate, private universities should be accredited by the HEAC who applies two different standards of accreditation, general and specific. HEAC determines the upper limit of students each university is allowed to admit in each program, in accordance with the number of staff and facilities available in that program. It is left to the universities to admit their own students provided they adhere to the admission policy and criteria as mentioned above, and to the numbers determined by HEAC. Moreover, each university is responsible to conduct a self evaluation process that includes assessment of new courses and units of study; review of courses, units and departments; and student evaluation of teachers. Part of the challenge has been ensuring that private universities do not dilute teaching quality with excess intakes. According to Cochrane (2006, August 25), the HEAC has penalized private universities with fines of 50,000 dinars $(£ 38,000)$ for enrolling too many students.

Sharaf (2007) and Yaghi (2008) believe that the current general accreditation system in Jordan is more of a licensing process than accreditation according to international standards. In an interview with Sharaf (2007, March), Chairman of Philadelphia University Board of Trustees, she asserted that the current accreditation system focuses more on quantitative than qualitative criteria that considers graduates' quality, the learning process, faculty's scientific research and the contribution of university's social responsibility contribution, as it is practiced in developed countries. Yaghi (2008, September 25) argues also that the specific accreditation granted to universities, according to the ratio of students to faculty and available facilities, does not ensure that universities are excelling in their performance, which should be the case in any accreditation scheme.

Financial Risk: Companies own private universities. Not only do they finance themselves, but they also make a profit that goes back to the owners. Student fees at private universities are, in general, much higher than the fees at public universities (TEMPUS, 2010 and Kanaan, et al., 2009). In addition, they often try to spend as little as possible even in issues related to teaching. Moreover, neither private universities 
nor their students receive financial support from the government. The private university must pay a onetime accreditation fee of $J \$ 15,000$ per department and an annual tax of 25 percent of profit to the government (TEMPUS, 2010). However, private universities receive donations from affluent individuals, shareholder investors, and private business corporations in Jordan or abroad (Al-Basheer, 1998). It is noticed, however, that programs offered by private institutions tend to concentrate more in areas of liberal arts, business administration, computer sciences and technology in order to insure a higher profit margin (TEMPUS, 2010). In the early 1990s, private universities were allowed to charge tuition fees, which vary from university to university and field of specialization, high enough to cover their running costs plus commercial profit that rewarded their owners' investment (Ababneh, 2004). Youth activist, the National Campaign for Defending Students' Rights "Thabahtoona" (meaning you slaughtered us) which was established in 2007, has supported student protest against fee hikes in Jordanian universities. Lawmakers also have criticized Private Universities' Law for not allowing the government to interfere with private university fees, calling on the state to protect students studying at private universities (Kheetan, 2008).

Kanaan et al., (2009) realized also that expenditure per student in 2007 was JD 1594, almost unchanged from the average for the period 2003-2007, and that capital outlay per student in 2007 had declined significantly in private universities to only JD 76 relative to the average of JD 139 during the same period. Moreover, Kanaan et al., (2009) observed only a small proportion of expenditure allocated to capital formation in private universities, which they believe, is an indicative of limited improvement. Capital expenditure of private universities, which covers spending on assets that last longer than one year and includes spending on the construction, renovation and major repair of buildings, averaged 9 percent of the total for the recent five year (2003-2007), although private universities are new and believed to be intensifying their facilities. According to Kanaan et al., (2009), capital expenditure by private universities both in absolute terms as well as a proportion of total expenditure has been continuously declining for the last five years (as illustrated in Table 2).

Table 2: Private Universities' Expenditure by Category (2003-2007)

\begin{tabular}{|c|c|c|c|c|c|c|}
\hline \multirow{2}{*}{ Year } & \multicolumn{2}{|c|}{ Current Expenditure } & \multicolumn{2}{|c|}{ Capital Expenditure } & \multirow{2}{*}{$\begin{array}{l}\text { Total } \\
\text { Expenditure } \\
\text { JD }\end{array}$} & \multirow{2}{*}{$\begin{array}{l}\text { Tuition Fees } \\
\text { JD }\end{array}$} \\
\hline & JD & $\%$ & JD & $\%$ & & \\
\hline 2003 & $60,206,658$ & $81 \%$ & $14,427,388$ & $19 \%$ & $74,634,046$ & $90,468,559$ \\
\hline 2004 & $73,409,441$ & $93 \%$ & $5,876,810$ & 7\% & $79,286,251$ & $96,016,542$ \\
\hline 2005 & $78,356,817$ & $94 \%$ & $5,196,436$ & $6 \%$ & $83,553,253$ & $104,983,125$ \\
\hline 2006 & $83,505,856$ & $94.5 \%$ & $4,860,129$ & $5.5 \%$ & $88,365,985$ & $110,206,729$ \\
\hline 2007 & $87,189,121$ & $95 \%$ & $4,395,339$ & $5 \%$ & $91,584,460$ & $113,379,758$ \\
\hline
\end{tabular}

The declining trend of capital formation in private universities, Kanaan et al., (2009) believe, could have adverse effects since it suggests that productive capacity (university educational and research facilities) is not catching up with the intensity of capacity utilization required by the rising numbers of students enrolled.

Reputational Risk and Image of the Private University: Sarayrah (2003) indicates that image of the private university in Jordan is a product less of the private universities themselves and more of the prejudice expressed by members of the public university community. Resentment arises of the fact that students "pay" for their education, and indications of unfair practices and substandard education proliferate on the one hand, and that private universities pay better salaries on the other, but on a contract basis without the expectation of tenure. Whereas faculty members in the public universities are guaranteed employment for life after two years of service and frequently choose this security rather than taking the risk associated with a private institution's higher salary. However, many faculty members of public universities spend their sabbatical teaching at private universities and although rarely mentioned, a substantial number of public university officials and faculty members own shares in private university companies. Moreover, many interviewed faculty members of private universities expressed their complaint of that private universities admissions standards are lower than those of the public universities. This denotes to many of them dealing with less enthusiastic and eager students. University admission is based on the results of the (Tawjihi) the General Secondary School Certificate Examination. The qualifying score is 65 percent for public universities and 60 percent, or sometimes 55, for private universities. In addition, private universities have, in most cases, not developed adequate programs and 
projects to serve local communities and participate in their development, which could have helped in constructing a positive image of private universities in Jordan.

\section{Conclusion and Recommendations}

This study aimed to assess the most susceptible issues to risk facing private higher education institutions in Jordan. Private universities in Jordan have evolved considerably in the past twenty years, but still a lot needs to be achieved to keep them up with a rapidly growing knowledge based economy. The assessment of the drivers of risk in this study is important and relates to private as well as public universities in Jordan. Previous analysis suggests that the most apparent risk factors inhibiting private universities include, among other things: the quality of academic programs and educational delivery system (comprising students, faculty and executive management; utilization of new technologies, regional and international competition, escalating students' violence, demographic challenge, compliance with accreditation standards, and reputational risk.

The development, both in number of universities and enrolled students, puts private universities in front of various risks and challenges. Nowadays, quality issues and output of higher education institutions dominate the higher education debate in Jordan. This necessitates laying more efforts to overcome the difficulties and recognize a balance between the spread of higher education from one side, and the level of its quality from the other. The findings suggest that although private universities in Jordan are making some progress in determining and assuring quality in higher education, however, they are still inadequate. Sabri and El-Refae (2006) assert that Jordan needs a more rigorous quality assurance and accreditation system to promote and improve quality processes and outcomes as well as disseminate good practices.

Understanding the factors that are most likely associated with risk in private higher education is required and timely. Private higher education sector is required to reinforce its role of service to society through linking higher education with world of work; constructing cooperation with the government and other official groups; constant revision of curriculum; revising the teaching and learning techniques; guiding research to serve the different segments of the economy; and serving the other levels of the education system. To achieve this, leaders of the private universities in Jordan need to explore and assess the full range of risks that they face and develop risk management plans, which eventually will have an impact on their risk management processes. In addition, the governing body is responsible to ensuring that appropriate risk management activities are functioning effectively. However, the extent to which risks are embedded in the institution and how it is defined vary from one university to another. Setting individual plans is adequate and learning from other international academic institutions on how to manage risk can also be helpful. Many international institutions of higher education are moving from achieving technical compliance with accreditation requirements, and are now looking to realize the benefits of having implemented risk management (HEFCE, 2005). These include the ability to take better-informed decisions about opportunities, and constructively address new patterns of risk. Risk management thus helps maintain and improve the quality of education and research provided by an institution.

Finally, the following suggested key elements can help private universities to become effective at managing risk (Cassidy et al., 2001):

1) Acceptance of risk management framework as the focal point and common language for everyone in the organization

2) Senior management must be committed to embrace the need for an evolution to an integrated risk management framework

3) A chief risk officer, or another member of management, must be designated to implement the program and work with each business unit, leveraging its knowledge and its operating line individuals.

4) An integrated risk management framework must be communicated throughout the organization.

5) Staff must be mobilized with effective training

6) Human resource mechanisms must be developed that establish accountability and reward effective behavior

7) There must be a risk management process in place that identifies opportunities for sustainable competitive advantage and permits timely corrective action to mitigate the risk

8) The internal audit department should be viewed and empowered as an agent to assess and improve risk management practices 


\section{References}

Ababneh, R. I. (2004). Financing higher education in Jordan: The costs and benefits of policy innovation. Doctorate Dissertation, (UMI No. 313493). Retrieved September 30, 2010 from Pro Quest database.

Abu-Rumman, H. (2008, September 25). Private Higher Education in front of an abundant crisis: private universities a success story hindered by profit-making and bureaucratic beliefs. Al-Sigel, 45 (1), 1, Amman: Jordan, Al-Mada Company for Journalism and Information

Al-Basheer, S. (1998). Financing higher education in Jordan and the role of university investment funds in self-financing: Jordanian universities' experience. Unpublished Doctoral Dissertation. UmDurman University, Sudan

Al-Farawati, O. (2001). A Report cites minimal penetration of IT in higher education system. Jordan Times Newspaper, Amman: Jordan.

Al-Maani, W. (2008). The current state of higher education in Jordan: a critical point of view. Al-Ghad Newspaper, Amman: Jordan.

Al-Maani, W. (2002). Higher Education in Jordan: A vision for the Future. A Paper Presented at the Conference on Futuristic outlook on Higher Education in Jordan. 15-16 September, Amman: Jordan

Al-Qaraleh, M. (2007 May). Higher education in Jordan has transformed into business. Fact International, Online, www.factjo.com

Al-Zubaidi, A., and Al-Zubaidi, H. (without date). Suggested Iraqi Strategy for restructuring qualified Iraqi immigrants, Online, http:www.parliament.iq/206.doclk

Arab Human Development Report (AHDR) (2003). Building a Knowledge Society. United Nations Development Program and Arab Fund for Social and Economic Development, New York, Online, http://www.arab-hdr.org/publications/other/ahdr/ahdr 2003e.pdf

Arabeyat, S. (2008). Private Universities: unequal marriage between Science and Capital. Al-Sigel, 48 (1), 8, Amman: Jordan, Al-Mada Company for Journalism and Information.

Badran, I. (1985). The Imbalance of Educational Structures. Amman: Jordan, Dar Al-Shurouq.

Bataeineh, M. (2008). A Historical Investigation on the Establishment and Development of Higher Education in Jordan. Doctorate Dissertation. Northern Illinois University, Illinois: United States (UMI No. AAT 3338768), Retrieved October 21, 2010, from Pro Quest database

Burke, D., \& Al-Waked, A. (1997). On the Threshold: Private Universities in Jordan. International Higher Education, 9 (November 1997), 20-22, Boston College: Centre For International Higher Education, Online, www. bc.edu/b c_org/avp/soe/cihe/newsletter/ihe.pdf/ihe09.pdf

Cassidy, D., Goldstein, L., Johnson, S. L., Mattie, J. A. \& Morley, J. J. E. (2001). Developing a Strategy to Manage Enterprisewide Risk in Higher Education.

White paper presented to the National Association of College and University Business Officers (NACUBO) and PricewaterhouseCoopers, Online, www.pwcglobal. com/ Extweb/pwcpublications.nsf/docid or http://www.nacubo.org/Business_and_Policy_Areas/Risk_Management.html

Cochrane, P. (2006). Jordan reins in private sector. The Times Higher Education, Online, http://www.timeshighereducation. co.uk/ story. asp? Story Code $=204963 \&$ sectioncode $=26$

El-Gharaybeh, A.K. (2004). Me and the University: Fifty Years of Hope and Despair. Al-Rai' Newspaper, Amman: Jordan

El-Tarawneh, K. (2010, March 13). Accreditation of Higher Education in Jordan. A lecture presented at Petra University on March 13, Amman: Jordan.

Ethics Point (2004). Higher Education Risk Factors and Definitions. A White Paper, Online, www.ethicspoint.com

Helsloot, I. \& Jong, W. (2006). Risk Management in Higher education in the Nederland. Journal of Contingencies and Crisis Management, 14 (3), 142-159.

Higher Education Funding Council for England (HEFCE) (2005). Risk Management in Higher Education. $A$ Guide to Good Practice, prepared by PricewaterhouseCoopers on behalf of HEFCE, February, 2005/11, Online, www.hefce.ac.uk/pubs/hefce/2005/05

Kamal, M. (2007). Higher Education seminar criticizes the MOHE and HEC decisions. Arab Legal Information Network, Online, www.eastlaws.com

Kanaan, T., Al-Salamat, M., \& Hanania, M. (2009). Financing Higher Education in Jordan. Jordan Center for Policy Research and Dialogue (JCPP), Amman: Jordan, Online, http://www.jcpprd.org/Files/ResearchDatabase/Financing\%20Higher\%20Eduction\%20in\%20Jor dan.pdf 
Kheetan, T. (2008). Higher Education Ministry to look into private university fees. Jordan Times Newspaper, Online, http://www.jordantimes.com/?news=10149

Kloman, F. (1992). Rethinking Risk Management. The Geneva Papers on Risk and Insurance, 17 (64), 299313.

Krieger, Z. (2007, a). Saudi Arabia Puts Its Billions behind Western-Style Higher Education. The Chronicle of Higher Education, 54 (3).

Krieger, Z. (2007, b). Dubai, Aiming to Be an Academic Hub. The Chronicle of Higher Education, 54 (8).

Mahmoud, A. (2004). On the course of Higher Education: Words not short on criticism. Al-Rae' Newspaper, 28, Amman: Jordan.

Mazawi, A. M. (2004). Geopolitics and University Governance in the Arab States. International Higher Education, 34 (Winter 2004).

Ministry of Higher Education and Scientific Research (2010). Notes on Higher Education System. Data for Academic year 2009/2010, Amman: Jordan, Online, www.mohe. org.jo

Ministry of Planning (2000). Cluster Studies. Higher Education Cluster 2000, amman: Jordan, Online, www.mop.org.jo

Murad, N. (2010). Violence. Opinion, Jordan Times Newspaper, Amman: Jordan, Online, http://www.jordantimes.com/index

Myers, M. (2000). Qualitative research and the generalizability question: Standing firm with Proteus. The Qualitative Report, 4 (3/4), Online, http://www.nova.edu/ssss/QR/ Myers.html

Ortmann, A, College, B. \& Squire, R.C., (1998, May). The Internal Organization of Colleges and Universities: A Game-theoretic Approach. A revised version of PONPO discussion paper \#232 (1996), Harvard Business School.

Sabri, H. \& El-Refae, G. (2006). Accreditation in Higher Business Education in the Private Sector: The Case of Jordan. Journal of Marketing for Higher Education, 16 (1), New York: Best Business Books: Haworth Press.

Sarayrah, Y., K. (2003). Resistance to Innovative Teaching Methods in Public Administration Education in Jordan. A paper presented to the International Association of Schools and Institutes of Administration (IASIA) conference on Public Administration: Challenges of Inequality and Exclusion, Miami, 14-18 September, 2003. Online, www.mop.gov.jo/partners/issue42_nov/page2.html

Sharaf, L. (2007, March). Challenges facing Private Universities in Jordan. A private interview with the researcher.

Sharaf, L. (2007, August). Higher Education Seminar criticizes MoHESR and HEC. Arab Legal Information Network, Online, www.eastlaws.com

Temple, B. (1997). Watch your tongue: issues in translation and cross-cultural research. Sociology, 31 (3), 607-18.

The Economist (2005, February 26). Free degrees to fly- Already a big global business, is higher education poised for take-off? Higher Education, Industry Overview, the Economist, Online, http://www.economist.com /node/3690585? Story id =3690585

Trans-European Mobility Program for University Studies (TEMPUS) (2010). Higher Education in Jordan, Jordan Final 11-7-2010. National Tempus Office, Amman: Jordan, European Commission, Online, http://www.tempus. org.jo /Higher Eductaion.html

United Nations Development Program (UNDP) (2009). Online, www.undp.org

Webster's Third New International Dictionary (1981). Springfield, Massachusetts: Merriam-Webster (p. 1961).

Whitefield, R. (2004). Creating a Risk-Conscious Climate Risk: Risk, both physical and financial, is part of the planning fabric as never before. National Association of College and University Business Officers, Online, www.ethicspoint.com/en/files/ rickwhitfieldpdf

World Bank (2009, April 21st). Higher Education Reform for the Knowledge Economy Project. Project Appraisal Document, Washington D.C.: World Bank. Online, http://web.worldbank.org/external/projects/main?pagePK=64283627\&piPK $=73230 \&$ theSite $P K=40941 \&$ menuPK=228424\&Projectid $=P 102487$

World Bank (2008). The Road Not Traveled: Education Reform in the Middle East and North Africa. MENA Development Report, World Bank, Washington D.C.: World bank, Online, http://web.worldbank.org/WBSITE/EXTERNAL/COUNTRIES/ MENAEXT/0,_contentMDK:21617643 pagePK:146736 piPK:226340 theSitePK:256299,00.html

Yaghi, A. (2008, September 25). Intermediate Learning: an alternative route connecting secondary with academic education. Al-Sigel, 45, (1), 12, Amman: Jordan, Al-Mada Company for Journalism and Information. 